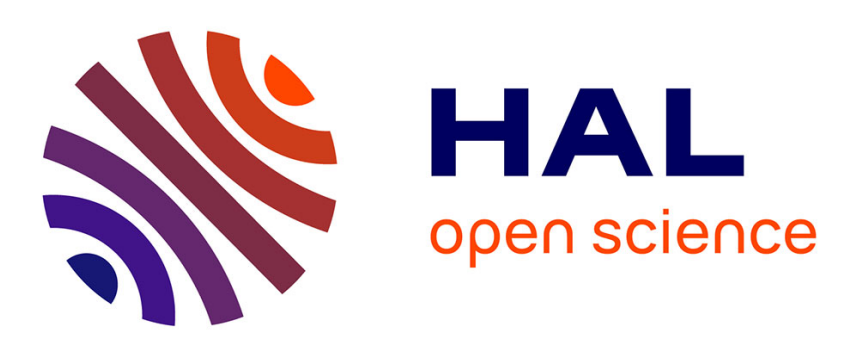

\title{
Gesture as a device for converging of sensory and semiotic modes and levels. The case of Argentinian tango
}

Valeria de Luca

\section{- To cite this version:}

Valeria de Luca. Gesture as a device for converging of sensory and semiotic modes and levels. The case of Argentinian tango. Punctum: International Journal of Semiotics, 2017, 3, pp.57 - 75. 10.18680/hss.2017.0006 . hal-01706463

\section{HAL Id: hal-01706463 \\ https://hal-unilim.archives-ouvertes.fr/hal-01706463}

Submitted on 14 Feb 2018

HAL is a multi-disciplinary open access archive for the deposit and dissemination of scientific research documents, whether they are published or not. The documents may come from teaching and research institutions in France or abroad, or from public or private research centers.
L'archive ouverte pluridisciplinaire HAL, est destinée au dépôt et à la diffusion de documents scientifiques de niveau recherche, publiés ou non, émanant des établissements d'enseignement et de recherche français ou étrangers, des laboratoires publics ou privés. 


\section{Gesture as a device for converging of sensory and semiotic modes and levels. The case of Argentinian tango}

\section{Valeria De Luca}

In recent decades, semiotics has shown an increasing interest in the passion and body dimensions of meaning. In particular, the growing emphasis on the role of bodily presence in semiotics has extended semiotic reflection to issues like embodiment, intersubjectivity, interactions and practices. In this context, a certain absence is noticeable regarding a field of reflection that is crucial for testing semiotic theoretical and methodological tools. This field concerns dance, that has been approached only marginally because of the challenges encountered in its analysis. Our contribution aims, first of all, at showing how the notion of gesture allows us to understand the passage from a sense of movement to the constitution of a cultural identity and imaginary based on bodily interaction and on the divers forms it assumes. We will will focus our attention on Argentinian tango and the principles of tango movement, in an attempt to grasp the features of tango bodily interaction. Subsequently, this will allow us to highlight the close link between a strictly bodily level of semiosis and that concerning the social practice of dancing.

KEYWORDS Argentinian tango, dance, gesture, body interaction, empathy, intersubjectivity

\section{Introduction}

The paper aims to examine the semiotic contribution to the study of dance and, in particular, the semiotic models by means of which it is possible to link the bodily and sensory dimension to all the other dimensions that are involved in dancing, conceived as social and cultural phenomenon. For this purpose, we will firstly examine the theoretical relationship between dance and semiotics, as well as certain methodological problems that arise in studying 
dance form a semiotic point of view. Secondly, we will focus our attention on Argentinian tango, approached as a 'whole' phenomenon, in which bodily practice and cultural levels are closely linked. In this regard, we must make clear in advance that the cultural dimension, strictly speaking, will remain in the background of our reflection because of limits of space. We should specify here, that the analysis of bodily dance principles and of bodily dance interaction is part of a broader model of semiosis of practice, exemplified, in the case of tango, by the milonga. In brief, we conceived of a model that holds together syntagmatic constraints (according to Fontanille's model) and morphodynamical issues (drawing from notions such as 'form', 'figure' and 'morhogenesis', found in Thom 1990, Cadiot and Visetti 2001).

We will outline an imbricated analysis of these different dimensions, starting from notions like gesture and from Jacques Fontanille's model of levels of pertinence in generating the plan of expression (Fontanille 2008). In particular, we will describe some bodily - and, at the same time, cultural and historically defined - features of tango dancing in order to understand which kind of sensitivity is developed. In spite of the great importance immediately accorded to vision during the dance, we will highlight the role played by contact, not only physical contact but notably the kinesthetic one, driven by the so-called marcación, an enunciative body tool that configures the dancing contact and allows dancers to create gestural figures. This will lead us to think differently, in a semiotic perspective, about the notion of empathy, a key-concept in the study of dance interaction.

\section{Semiotics and dance: an insight}

In studying dance from a semiotic epistemology, we are confronted with a variety of possible approaches. Our first task is to determine which semiotic method is most appropriate to the range of values associated with the phenomenon under study. This not only implies certain choices regarding the size(s), level(s) and unit(s) of analysis, but also a vigorous reflection on the nature of semiosis itself. At first sight, dance does not seem to make sense, given that it cannot relate to the linguistic concept of the sign. On the other hand, there is the quantitative problem that there is a rather small number of researches on dance both in its generality and on particular dances. At the same time, from a qualitative viewpoint, dance is treated differently by different authors: i) as a repertoire/inventory of figures, modular units that allow the introduction of parallelisms with popular tales, as in the case of the work by Ciortea and Giurchescu (1968); ii) as a full-blown theoretical object, according to René Thom (1990); as an emblem of a certain semiotic regime, according to Eric Landowski (2005); iii) as a case study of an analytical model, such as the path through pertinence levels in Jacques Fontanille; iv) finally, as an autonomous meaning system, fully independent from language, according to Göran Sonesson's (2009) research on iconicity. So, an epistemological split exists between dance semiosis 
as a particular case of general gestuality, and a semiosis that takes into account gestuality in specific dances as complex socio-cultural facts.

Greimas highlighted the challenge of a semiotic approach to dance, by stating that:

la danse est un problème qui fait partie d'une problématique de la gestualité en général et de l'expression corporelle somatique. C'est le corps qui est un langage ; le corps en mouvement avec la gestualisation. La danse y apparaît comme un non-sens, tout comme le cinéma. Pour qu'une analyse puisse être faite des arts en mouvement, il faut l'immobiliser, le stabiliser, d'où la nécessité d'une écriture de la danse ou d'une poétique de la danse qui est la condition nécessaire pour pouvoir étudier la danse elle-même. (Greimas 1986: 42)

In Greimas' conception of the moving, gesticulating body as a language, the only possibility for approaching and analyzing gestures as movement acts consists in arresting movement itself. The constitution of movement as an investigation object, in other words, necessitates the exclusion of the actual phenomenon under study. This contradiction would make the analysis a kind of notation of movement or, more generally, a sort of writing project, in order to translate the relations that are supposed to organize and articulate gestures. In other words, the system used as model is the semio-linguistic one, even if Greimas underlines the continuous nature in a constant stabilization process - of gestures. On the one hand,

la gesticulation, apprise et transmise, tout comme les autres systèmes sémiotiques, est un phénomène social. [...] la gesticulation est une entreprise globale du corps humain dans laquelle les gestes particuliers des agents corporels sont coordonnés et/ou subordonnés à un projet d’ensemble se déroulant en simultanéité. (Greimas 1968: 12)

On the other hand, it seems almost impossible to segment 'gestural text in meaningful syntagms, other than through the semantic of natural languages' (Greimas 1968: 16). According to Greimas, this difficulty is due to so-called désémantisation, that is, the unstable nature of units supposed to form a gestural syntagm, in terms of their meaning function and status. In other words, it is hard to determine which unit can be classified in a sub-morphemic layer or, on the contrary, in a larger syntagmatic chain, and when it occurs.

However, if a gestural substance allows us to assume a gestural form (in hjelmslevian terms) behind it, made up of global cultural projects and programs, then the analogy between dance and language can be kept, at least partially, provided that we get out from a strict analogy between figures/gestural programs and the two aspects of the linguistic sign, i.e. the double articulation model. Starting from Greimas' hypothesis of a practical gestuality, Julia Kristeva suggests that gestuality should be considered itself as a practice, as an activity rather than as an act. Specifically, she claims that: 
60 Gesture as a device for converging of sensory and semiotic modes and levels

la gestualité [...] est susceptible d'être étudiée comme une activité dans le sens d'une dépense, d'une productivité antérieure au produit [...] Évidemment, le geste transmet un message dans le cadre d'un groupe et n'est que 'langage' que dans ce sens, mais plus que ce message déjà là, il est (et il peut rendre concevable) l'élaboration du message, le travail qui précède la constitution du signe (du sens) dans la communication. (Kristeva 1968: 50)

By conceiving gestures as a practice, as an activity, Kristeva grasps the relationship between gestuality and semiosis giving primacy to movement. Following Kristeva, a distinction can be made between gestuality as a generic activity that constitutes fields of relations, and gestures as acts, however ephemeral, that modulate body interactions, as in the case of dance. Having discussed this point extensively elsewhere (De Luca 2016), we should, however, note that this kind of double articulation, radically different from the linguistic one, allows us, on the one hand, to better grasp the semiotic modes of emergence and stabilization of tango as a dancing form and, on the other hand, to study and describe its specificities as deployed both by subjects' bodies and in other attested forms. A similar perspective is found in Susanne Langer's works, especially in her book Feeling and Form (1953), where she develops her view of the expressive form based on Ernst Cassirer's philosophy of symbolic forms and the principles of Gestaltheorie. In this framework, dance is not produced as a symbolic form through mere movement: dance emerges when gesture is virtual, imagined, transposed and, consequently, reflexive. That is what she calls primary illusion:

What, then, is dance? If it be an independent art, as indeed it seems to be, it must have its own 'primary illusion'. Rhythmic motion? That is its actual process, not an illusion. The 'primary illusion' of an art is something created, and created at the first touch-in this case, with the first motion, performed or even implied [...] Only when the movement that was a genuine gesture is imagined, so it may be performed apart from the squirrel's momentary situation and mentality, it becomes an artistic element, a possible dance-gesture. Then it becomes a free symbolic form [...] Dance gesture is not real gesture, but virtual. ${ }^{1}$ (Langer 1953: 174, 175, 178)

But what does primary illusion mean? In Langer's perspective, shaping forms is not only a perceptive activity that organizes lived experience from a sensory point of view, but it also represents an inaugural moment of symbolic emergent activity, or, in other words, a moment of creation of meaning, of meaningful relations. This activity, which Langer calls a 'presentational symbol', allows her not only to recognize reality as a deployment of a landscape of 'mere' forms, but also to understand an emerging distribution of values, in the sense that forms condense simultaneously a perceptive activity and socio-cultural interactions. Medium and reflexive features of gesture are examined also by Giorgio Agamben (1991), when he looks 
at Latin etymology of gesture and relates that to the concept of forms of life. Starting from Varron's distinction between ăgĕre (act), făcĭo (make, perform) and gĕrĕre (manage, handle), Agamben notices that 'ce qui caractérise le geste, c'est qu'il ne soit plus question en lui ni de produire ni d'agir, mais d'assumer et de supporter. Autrement dit, le geste ouvre la sphère de l'éthos comme sphère la plus propre de l'homme' (Agamben 2011: 189). The openness to an ethical horizon is offered by a specific type of action that the gesture unveils:

si le faire est un moyen en vue d'une fin et l'agir une fin sans moyens, le geste rompt la fausse alternative entre fins et moyens qui paralyse la morale, et présente des moyens qui se soustraient comme tels au règne des moyens sans pour autant devenir des fins. (Agamben 2011: 189)

Therefore, gesture mediates between ends and means, and seems to install a specific space between potentiality and action, to the extent that is makes visible means and modes as such. In other words, the visibility of mediation as the primary modality of the relation between subject and environment, and as a prerequisite for constituting esthetic form, makes gesture the emblem of all semiosis. From a semiotic point of view, we can observe some important consequences: 1) gesture, by drawing attention to the subject's awareness of the mediated nature of his actions, requires that valuation systems work both at an individual level (as modes of subject involvement) as well as at the collective level; 2) by making medium visible as an expression, gesture problematizes the enunciative praxis, in view of the different mediations that are entangled in the body; 3) for this reason, gestural activity could imply the inquiry of its traces or other forms that constitute its expressive power. In this perspective, recent semiotic studies focus their attention on forms and modalities of body and practical interaction. Among these, we find Eric Landowski's interactional model, based on the idea of adjustment between inter-actants, and Jacques Fontanille's semiotics of practices. In the case of Landowski, adjustment is a particular regime of interaction that includes the sensual, bodily and lived dimensions, all the while emphasizing the idea of an emergent co-construction of meaning during the interaction. This co-construction is closely linked with the French notion of épreuve as both an experience and a test, a proof; a sensitive 'test' that helps us understand the specificity of those types of interaction, in which mutual fulfilment doesn't come from fusion but from autonomous and coordinated responsibility of action. Dance is emblematic in this respect:

si je veux, en dansant, interagir avec l'autre d'une manière qui fasse vraiment sens en mon propre corps, il ne suffira pas que j'attende de l'autre qu'il suive correctement les 'pas' codifiés de la danse que nous dansons [...] En revanche, si j'aspire [...] à une relation sensible créatrice de sens et de valeur, il faudra en premier lieu que je fasse moi-même en sorte que mon partenaire puisse [...] s'exprimer à son gré [...] le traiter, 
62 Gesture as a device for converging of sensory and semiotic modes and levels

sur le plan gestuel et somatique, comme un véritable co-énonciateur. (Landowski 2004: 28)

However, dancing interaction not only involves 'mere' bodies in mutual adjustment but, more precisely, it lies at the crossroads between at least two meaning and expression levels, i.e. following Fontanille's model, body-objects and practices. In this perspective, practices integrate and transpose certain bodily properties in a scene in order to constitute available forms for other broader configurations of meaning. In other words, it is a question of grasping through the body, transformations of perceptive valences in practical axiologies that can affirm themselves as vehicles of identity and cultural construction. Such a perspective allows an examination of dance by other semiotic forms. Fontanille states that:

on pourrait être tenté de reconnaître des pratiques [...] directement ancrées dans une 'topo-chronologie déictique', centrées sur un corps de référence, comme la danse [...] cette topo-chronologie est une structure d'accueil qui fait signifier des corps, et pas seulement comme centre de référence déictique, mais aussi dans toutes leurs propriétés de corps [...] ce ne sont pas des objets au sens courant, mais ce sont pourtant des supports d'inscription: l'expression chorégraphique consiste justement à inscrire des figures sur les corps des danseurs [...] Le cas de la danse [...] répond parfaitement aux critères d'une pratique, schématisable en 'scène prédicative' [...] il intègre de toute évidence [...] des 'ajustements' entre les corps en mouvement (Fontanille 2008: 60, 62).

As will be discussed in the following section, some bodily and dancing principles of Argentinian tango show this entanglement between sensoriality, interaction and practice.

\section{Body and gesture in Argentinian tango}

As we demonstrated elsewhere (De Luca 2016), Argentinian tango can be defined as a complex and transcultural set of gestural repertoires (choreography, steps, figures), textual productions (letras, i.e. tango songs' lyrics), normed practices (the milonga, i.e. dance evenings and ballrooms, dance spectacles such as world competitions and demonstrations, but also learning practices, musical performances etc.) and institutionalized cultural imaginaries (literary and trans-national stereotypes, such as el compadrito, la milonguita, or icons like the singer Carlos Gardel, or even poeticized emotions like nostalgia and idealized periods in music/dance history, like the 'golden age' of thirties and forties of the twentieth century). Tango emerged in last decades of nineteenth century around Buenos Aires (cf. Salas 1989) as a dance and music practice born from the hybridization between various ethnic and social groups of immigrants 
coming both from the interior of Argentina and from abroad. Tango's roots have been a matter of intense debates. Opinion is split between its poor and black origins in the orillas ${ }^{2}$ and arrabales $^{3}$ of Buenos Aires, and its upper-class appropriation and refinement by Argentine urban society. However, we know that tango dancing and tango practice - the milonga - are improvised and progressively normed by their own driving habits. With respect to the dance, tango introduces several gestural novelties in pair dancing. As the ethnomusicologist Carlos Vega (1967) has observed, the major innovation in this regard was the insertion of the figure in the space of couple, drawing from two traditional 'principles': the corte and the quebrada. We describe corte and quebrada as 'principles' in the sense that they are not mere figures or steps, but a sort of gestural forms that promote another kind of bodily contact and interaction, that comprise the typical tango embrace, the abrazo. The dancer and tango teacher (maestro) Rodolfo Dinzel suggests that:

avec le tango, une nouvelle mécanique surgit dans le champ des danses de couple, une modalité véritablement révolutionnaire qui consiste en l'invasion de l'espace inférieur du partenaire. Qu'est-ce que cela veut dire? Cela signifie que le danseur [...] utilise ses jambes à l'intérieur de l'espace réservé aux jambes du partenaire [...] Jusqu'à la fin du XIXe siècle, la possibilité de danser en occupant l'espace de l'autre était inconcevable, qu'il s'agît de danses populaires ou académiques. (Dinzel 1999)

In what follows, we will try to explain that, by conceiving tango principles as gestural forms, we can provide a better definition of the enunciative (and bodily) praxis of the agents (the dancers) during dance improvisation, in terms of chains of transposition of imaginary and culturally embodied patterns. That will lead us to conceive the tango couple as a bubble-actant, by interpreting it in a more plastic and irregular way, unlike some current interpretations which interpret it only in terms of empathic dialogue between agents. Before discussing the bubble-actant, however, let's firstly take a closer look at the impulso suspendido (suspended momentum) and the abrazo (embrace). Subsequently, the study of bubble-actant will allow us to introduce the notion of maración (generally speaking, a marking process) in order to reconsider empathy from a semiotic perspective.

\subsection{Suspended momentum}

During the tango dance, partners walk side by side embracing themselves in two possible ways: a traditionally closed embrace (abrazo cerrado) where chests are in with contact, or an open embrace (abrazo abierto) where the contact is imaginary. The leader (often a man), walks forward while the follower (often a woman), walks backward, carrying out original gestural sequences - whether these are specular or not. In other words, the gestures of each partner can 
be different in the composition and performing of a figure. Moving in space involves a deformation of linearity, that defines any type of figure in the walk (caminada). Any figure can in turn be performed whether on site or by walking. This possibility is allowed by what Argentinian dancer and psychoanalyst Lidia Ferrari (2011) calls impulso suspendido. It specifies the idea of a break expressed by corte, which indicates any suspension or interruption of a gestural chain that enables its transformation and the transition to a new figure. Impulso suspendido performs this pause in that:

lorsque l'on danse le tango, l'instant essentiel est celui dans lequel le pied se lève juste avant de s'appuyer à nouveau au sol. Il y a une impulsion, celle qui est conférée dans l'engagement du pas, qui peut être suspendue pendant que l'on danse ; puis, ce pied peut aussi bien retarder le contact avec le sol que l'accélérer [...] Cet instant est infinitésimal, mais la légèreté ainsi que la tension qu'il produit dans la danse sont remarquables [...] Le retard dans l'appui du pied au sol oblige le danseur à trouver un équilibre sur le seul pied qui non seulement soutient tout le corps, mais qui le fait tout en dansant. (Ferrari 2011: 27-28)

In other words, impulso suspendido creates an inner space-time in dance - a sort of gestural gap - that makes present the virtuality of gestures, i.e. it foregrounds the emergence of gestures by extending the moment of their constitution. It is through these gestural gaps that dancers receive feedback on their posture, balance and marcación. There is also a strong interdependence between impulso suspendido and abrazo, due to the muscular 'lag' introduced by abrazo, an imbalance which is highlighted as a founding element of dance contact.

\subsection{The embrace}

In order to walk in embrace, insert figures in the walk and, at the same time, avoid tripping over your partner's feet, tango dance developed ways enabling each dancer to negotiate differently his weight, as well as modes of weight-shifting between dancers. Redistribution of weight is performed by changing posture, especially by tilting the balance axis of each dancer; the new posture is called apile ${ }^{4}$ and therefore the abrazo thus formed is called abrazo apilado. Regardless of the tilt angle of each dancer's axis, redistribution of weight and forces - and consequently the imbalance generated from tilt - are organized through a specific relation to gravity and floor, and by taking different roles, whereby each body limb shapes the abrazo. Finally, in the tango embrace we can see: i) the key role played by the chest zone in terms of gestural suggestion/response (the 'active' side of marcación that, in short, doesn't reduce it to a simple affordance), balancing forces, directional control and spatial extension of the couple; ii) the support role played by the embrace form in determining the couple's borders, which 
are defined by the left hand of the follower placed on the right shoulder of the leader and by the right arm/hand of the leader placed on the follower's shoulder; iii) the role of gestural extension of the couple and a support role when the abrazo configuration is broken, played by specular contact between the follower's left hand and the leader's right hand.

The hand-arm-shoulder contact side is called the closed side of tango, whereas the hand contact configuration is called the open side of tango. Closed and open sides are not rigid structures; on the contrary, plasticity of embrace is essential to 'suggestion/response' dynamics. Deformability of abrazo is performed for example by modulating the size of circumference of the dancing couple through a slippage of arms on the closed side of abrazo or through a change in the tilt of the axis.

\subsection{The "bubble-actant"}

In Pratiques sémiotiques, Jacques Fontanille defines body-objects as 'des structures matérielles tridimensionnelles, dotées d'une morphologie, d'une fonctionnalité et d'une forme extérieure identifiable, dont l'ensemble est "destiné" à un usage ou une pratique plus ou moins spécialisés' (Fontanille 2008: 21). Generally speaking, practices are 'des “énonciations" de l'objet; à cet égard, l'objet lui-même ne peut porter que des traces de ces usages [...] c'est-à-dire des "empreintes énonciatives", leur "énonciation-usage" restant pour l'essentiel, et globalement, virtuelle et présupposée' (Fontanille 2008: 24).

On the one hand, a dancing body is as such both a surface of inscription and an acting material object; on the other hand, dance performance continuously updates the presupposed 'énonciation-usages'. This means that it is the point where an ascribed role converges with an achieved one. In tango, the first question is: what is inscribed in the body and how such inscription can occur? Do we actually inscribe only postural principles, as if they are action scripts always true to form? In our perspective, figures could be conceived also as real 'products' of enunciation in action, as gestures (both actions and acts) which lie at the boundary between débrayage and embrayage, by folding them over each other. What is, then, the appropriate actantial model for tango dancing interaction? Taking the couple as an actant seems plural and flexible, both from the outside and the inside. As maración shows, the 'lag' motif is profiled during the interaction by a distribution of actorial roles amongst the two partners. The couple-as-actant can be interpreted as a dual actant, in which the agents' bodies are more or less solidary and play several roles during their interaction. The adjustment of the couple-as-actant to the performance of gestures and to music, involves their (inter)action as if they were just one person, but, in reality, what we have is a duplication. Following Fontanille's model of the actant body (Fontanille 2004, 2011), the couple-as-actant can be subdivided into a Me-flesh and Self-own-body. In particular, flesh is 
66 Gesture as a device for converging of sensory and semiotic modes and levels

ce qui résiste ou participe à l'action transformatrice des états des choses, mais qui joue aussi le rôle de 'centre de reference' [...] la chair, ce serait l'instance énonçante en tant que principe de résistance/impulsion matérielles [...] la chair est aussi, du même coup, le siège du noyau sensori-moteur de l'expérience sémiotique. (Fontanille 2004: 22).

Self-own-body is 'ce qui se constitue dans la sémiose', as 'porteur de l'identité en construction et en devenir' (Fontanille 2004: 22-23). Me-flesh and Self-own-body, which are solidary and in a mutual presupposition, form two sides of the actant body, looking at the inside (sensory-motor animation) and at the outside (target/input), respectively. In dance, we can observe not only interaction or possible conficts between these instances, but also - from the point of view of gestural form - a specific way of configuring dancing bodies, as in the case of abrazo. To this end, we propose to conceive tango's couple-as-actant in terms of a bubble-actant, following Fontanille's statements on a sound semiotics. The image of a bubble replaces the image of sphere, widely used in sound studies, because

les limites du volume sont fluctuantes et en incessante déformation et déplacement [...] Le volume est animé par des masses en mouvement, des forces et des tensions entre masses, les moments critiques de ces mouvements et tensions donnant lieu à des événements. (Fontanille 2010)

By taking the couple-as-actant as the epicentre of movement, the dancing bubble is subject to surface tensions on the boundaries of abrazo, caused, for example by gravity, as in the case of an internal imbalance of one or both partners, by an 'echo' effect of other couples, or by any form of direct contact (brushing, crashing, pushing, invasion of space). Sustaining the bubble is ensured by processes such as: i) resistance to pressures and counter-balancing through opposition of its own energy mass and, ii) control of balance (adjustments between external and internal stresses).

These processes can be understood 'internally', whereby the bubble, starting from adjustments between the dancers' 'flesh' and envelopment, is approached as a source that resists to gravity and keeps its 'center' during moving, as well as during executing figures on the spot. In these cases, the processes at work are: i) the absorption and release of weight on the floor, with a swing of the forces of weight and inertia between partners, and ii) the establishment of a reference center (covalent bonds between marking points) that allows space occupation, exploration and penetration of the space, statically as well as dynamically. From these observations, two regimes or driving styles of interaction seem to be interwoven, a polemical style - related to somatic manipulation - and the other one, more linked to adjustment (Landowski 2005). The notion of marcación helps us to understand by what device the bubble-actant undertakes its course of action. 


\subsection{Enunciative marking}

The marcación (literally: marking) is the enunciative device by which gestural figures emerge in the space of abrazo, all the while it depends on the total field of the dance floor and, more generally, on dance practice. Both in tango studies and during tango learning, the marcación remains a fuzzy notion, which sometimes is generically considered as an intention, but in others it is thought to be embedded in given areas of the dancers' bodies. Generally speaking, marcación is defined as

l'intention du leader qui se réalise à travers sa main ou son bras afin de [...] guider le follower [...] On peut nommer marquage tout l'ensemble de signaux et de modes adoptés par le leader pour transmettre ce qu'il désire et ressent par le biais de la danse [...] Le marquage n'est pas que le mouvement de la main ou du bras : il surgit notamment du torse, du thorax. (Lala 20015:12)

Rodolfo Dinzel uses, for want of a better term, the words order/counter-order, by stating that the order

n'est ni plus ni moins qu'une perturbation du centre d'équilibre du partenaire, la proposition de stimulations pour qu'il réagisse sans perdre l'axe d'équilibre individuel et du couple. Les ordres sont des tensions sur l'axe et [...] doivent être communiqués au fur et à mesure, jusqu'à provoquer le movement. (Dinzel 1999: 35, 69)

Conceived in this way, marcación seems to focus more on the general path of a couples' movement (forward, backward, to the right, to the left), rather than on the co-formation of the gestural figure. The idea of projection raised in some studies, in order to describe the transfer of body weight - in particular in the absence of a real contact between chests - as well as the indication of direction of movement, seem to reinforce this observation.

Alternative interpretations of the marcación can be derived from aspects such as its effectiveness, even in the absence of torso contact, the perturbation of the partner's center balance, its specific length, which is not exclusively dependent on coordination with rhythmic musical accents, but also on other factors, and a partial emancipation of vision concerning its effectiveness. On the basis of the theoretical and methodological perspectives we develop here, interest in marcación concerns not so much muscular tension or movement, such as the degree of chests' reciprocal tension, the extension of steps, the length of rotation or the sudden contraction of arms in averting a collision with another couple of dancers. Marcación is interesting because it represents the enunciative device that contributes to managing the practical course of action from the point of view of the body.

In tango, we have observed that the bubble-actant is a dual actant which provides for 
two actorial roles, leader and follower. At the same time, these two roles are partially mixed. Specifically, at the beginning of the dance these roles are clearly distinguished and distributed between the two actors. During the subsequent interaction, however, each actor partially undertakes the other's role, because of his degree of involvement in marcación. Following, responding, accepting, refusing, perhaps compromising the conduct of dance are just a few of possible ways of engagement in interaction. That depends on double duplication: i) the constitutive duplication of bubble-actant, when it is considered as a unique body-actant, ii) the potential duplication of every actor, attributable to relationships between flesh and envelope (Fontanille 2004). In every moment of the interaction, and therefore, in every moment of marcación, the very nature of gesture generates a loop of débrayage/réembrayage which affects solicitations dealing with: i) envelope of bubble-actant and emerging gestural figures, ii) flesh of bubble-actant, iii) envelope of every dance partner, iv) flesh of every partner.

As a consequence, marcación complicates the status of the body-object, which is at the same time the support and the interface of inscription. Indeed, marcación reactivates the device/support of inscription by introducing variations of previous body inscriptions. This confirms the function of the device without limiting it to its instructional side. Marcación operates in a field of indetermination, in an imminence (Fabbri 2007) which prefigures the emergence and the stabilization of actants and of gestural figures. From this viewpoint, it can be configured as a device that we can include in the notion of enunciative praxis, insofar as

il n'y a de 'praxis' dans l'énonciation qu'en raison du mouvement qui la caractérise [...] La praxis énonciative 'navigue' [...] entre diverses formes immanentes [...] entre plusieurs devenirs possibles des trames narratives, pour les conduire vers la manifestation [...] la praxis énonciative transfigure le principe du 'mouvement' énonciatif en dialectique du même et de l'autre, de la stabilisation schématique et de l'innovation individuelle ou collective [...] comporte [...] une capacité de stabilisation ou de déstabilisation de formes [...] toute énonciation pratique est une exploration réflexive au cours de laquelle émergent et se constituent un ou plusieurs actant-corps auxquels peuvent être imputés les effets de la mise en procès et de la régulation de ce procès. (Fontanille 2014)

\section{Reweaving empathy}

Marcación leads us to put into question a common belief in tango, namely a conceptual overlap between the notion of empathy, intersubjectivity and the idea of an ecstatic fusion and unity. By contrast, a semiotic model based on gestural forms and figures, on practice and 
enunciation in action is not limited to description of sensorimotor areas or perceptive processes, but examines them as dimensions of making, as conditions of production of sense. Research in cognitive cultural psychology and, to some extent, in cognitive semiotics, tries to include in analysis the development of the dancers' body interaction; in particular, those aspects that concern synchronization between partners during improvisation, intersubjective constitution of dancers and the role of the space of milonga. Starting from the premise that tango interaction unfolds empathically, they seem to identify dancing interaction and practice with an irenic model of empathy. In fact, we can notice two quite distinct senses of empathy. As the psychiatrist Nicolas Georgieff explains,

le terme empathie [...] décrit le fait de connaître, en le partageant, l'état mental d'autrui, c'est-à-dire une expérience subjective qui témoigne de la transmission d'un état mental entre autrui et soi. Mais il définit aussi le processus objectif qui accomplit cette transmission, la réalité objective du mécanisme de reproduction d'une activité psychique par une autre. Le concept d'empathie recouvre donc sous le même terme la description clinique d'un état mental ou d'un processus psychologique, et l'explication de cet état, c'est-à-dire son mécanisme de production, dont l'état mental ou l'expérience subjective ne sont que le produit. (Georgieff 2008: 384)

The issue here is demystify the univocity of empathy when it is evoked in the context of improvisational tango interaction. Cooperation, synchronization of movements, co-deciding the management of steps and gestures in respect to the length of music and interaction, all of that should not fool us; an emphasis on identity is inscribed in empathy, as well as its inner dialectic between rapprochement and distance.

In summary, it is a question of complicating the idea that 'dans le tango, le corps propre fusionne avec le corps de l'autre pour faire un corps à deux. C'est la conquête de l'intérité' (Hess 2009). ${ }^{5}$ This complexity is allowed precisely by a minimal definition of empathy as the capacity to put oneself in someone else's place, whether with respect to embodied emulation of movement or to reaction to an emotional state. The ability to identify others goes together with the establishment of one's self. In this sense, empathy is part of intersubjectivity. Neurobiologist Jean Decety states that empathy

repose sur notre capacité à reconnaître qu'autrui nous est semblable mais sans confusion entre nous-mêmes et lui. Par conséquent [...] une autre caractéristique essentielle de l'empathie réside dans la distinction entre soi et l'autre, et ce parallèlement avec l'expérience d'un partage affectif. (Decety 2004: 54)

Therefore, the recognition of a common base of qualities and states leading towards a likeness is not a mere identification or a total matching between self and other. Every gesture 
70 Gesture as a device for converging of sensory and semiotic modes and levels

involves not only the development of action, but also a reflexive feedback in progress concerning the course of action; thus, empathic process is an activity at the same time neuronal, perceptive, intersubjective and social. As the philosopher Jean-Luc Petit argues,

en tant que produit de constitution active, qui dépend en son sens d'être du jeu de nos kinesthèses et du couplage empathique des systèmes kinesthésiques des différents agents, ce monde ne tolère pas le découpage entre un monde social et un monde physique [...] Quand on se met à la place d'autrui, c'est rarement pour observer 'ce qui se passe en lui', plus souvent pour s'assurer qu'on est bien dans le même monde. (Petit 2004: 140-41)

\section{Conclusion: A shared and social embodiment}

Previous remarks on empathy allow us to consider differently the imbrication between (dancing) body and practice in shaping intersubjectivity. On this subject, let us recall some suggestions put forward by Patrizia Violi about the status of the body in embodied cognition theories, as well as on the intersubjective nature of cognition. She underlines the existence of a 'corporal' excess in embodiment theories, that risk weakening the complexity of the body. She states that

There is [...] a risk present in contemporary theories of embodiment, which, paradoxically, could be described as an 'excess of body'. If, for centuries, the body did not appear to play any significant role in the mind's functioning, today one often faces an opposite situation, where almost everything seems to be located in the body - and, indeed, only there. (Violi 2009: 58)

According to Violi, the proliferation of the concept of embodiment, and consequently of theories generally based on the body, is made possible by the widespread use of an abstract notion of the body. In fact:

it alludes to a non-gendered, pre-discursive phenomenon, hiding the concrete reality of the many different bodies [...] with all their social, cultural, and discursive determinations. The concrete and variable reality of these individual bodies is often confused with the abstract notion of bodily or corporeal schemas and the role those schemas play in perception, cognition, and action [...] the risk [is] of hypostatizing the very notion of the body, at the same time making it an abstract and generic concept. Without contextualizing the processes that construct the body, one risks ending up 
by naturalizing the notion of body as something isolated and definable on its own premises - rather than a way of living in the world, acting in it, and making sense of it through one's acculturated body (ibidem).

While the risk of a hypostasis of body is suggested by the immediate, given nature of its own phenomenological experience, on the contrary, the semiotician emphasizes that it is in ordinary experience that the body appears as 'the result of a complex process and of the various practices that shape one's perception of it' (ibidem). However, in many embodiment theories, the body is conceived ultimately as a 'pure' form, modeled through excluding culture, habits, and practices. Following Violi, without taking in account these dimensions, 'one risks transforming it [the body] into a kind of ontological essence' (Violi 2009: 59). She notices the presence of such a restricted conception in cognitive linguistics as well as in semiotics. In relation to cognitive linguistics, Violi criticizes the schematicism that lies at the origin of conceptual and semantic oppositions based on the model of body schema. She claims another vision of embodiment, more dynamical and shared:

in order to understand the full nature of embodiment, one should move towards a more dynamic vision, taking into account the interaction of the body with its environment and the co-constructed nature of meaning - which, in turn, open up cultural meaning variations (Violi 2009: 60).

Finally, embodiment should not be taken to refer only to the bodily nature of cognition. It should rather be considered as a broader process of the co-constitution of bodies and cognition, conceived in a semiotic sense. Understanding embodiment in this way, implies a wider notion of the body itself, conceived as the biological, sensitive, intersubjective, social and cultural result of the interaction with the environment and with others. In particular, intersubjectivity is not only intercorporality, but it 'implies a semiotic dimension of meaning's social co-construction' (Violi 2009: 61). In conclusion, comprehension of intersubjective sense-making on which embodied cognition is based, needs to

move away from a mental/representational approach to a different view of cognition where meaning is distributed among actors and the mind is no longer the internal, individual apparatus where cognitive processes take place. It is rather replaced by an extended, 'external' mind (ibidem).

With respect to tango and its bodily features, we can finally provide a wider view on the links and the implications concerning the practical and the cultural levels. In order to understand the sharing and social embodiment implied by the device of marcación, we have to look at how the milonga is organized as a praxeological space (and not merely as a physical one). First of all, mi- 
longa is a normed and scenic space where the constitution of the dancing couple, its movements in space and the elements of improvisation, are prescribed and occur at the same time. This is documented by historical sources ${ }^{6}$ and it is today visible at the level of different tango dance styles. As we discussed elsewhere (De Luca 2016 and 2017, forthcoming), in our analytic model styles represent a 'strategic' level, located between practice and culture (in what Fontanille calls forms of life), where the social, normed and imaginary implications of a bodily set-up are clearly visible. Dance styles are transmitted by practice, but at the same time, in tango history, and they have been extensively investigated as the primary means to identify the authentic Argentinian quality of tango. The case of Tango World Championships is very instructive, in this respect (Morel 2013). In these high-profiled events, attitudes and styles originating in the informal practice of milonga become part of the strict rules of competition - mainly in the category of salon tango (tango de salon) rather than that of show or stage tango (fantasia) - with the aim to reproduce, protect and promote the genuine ambiance of milonga.

To get back to our starting point, styles inform dance embodiment by their mnemonic and practical power but, at the same time, they become singular and reflexive every time they are performed in improvisation. In other words, styles allow dancers to assume a reflexive stance in relation to their own bodily and social experience. In that sense, styles comprise a 'third' dancing body of tango: neither wholly personal, nor exclusively social, they are agents of an embodied process of differentiation of values and, consequently, of forms (bodily forms of dance and cultural lived forms of dancing encounter). Consequently, social and shared embodiment can be understood in terms of an experience of normativisation of culture, as enactivist cultural psychology claims by affirming that the question is 'to move away from an account of culture as an already established normative system and toward an account of culture as an ongoing stylization of a normativity that remains, so to speak, without positive terms' (Baervelt and Verheggen 2012).

\section{Notes}

1. For a deeper reflection on virtuality - in Deleuze's sense - and tango, see Manning's works, and in particular his Politics of touch. Sense, movement, sovereignty, where the author evokes the dimension of the 'in-between' as emblematic of tango interaction.

2. Litterally, the 'shore'.

3. Litterally, the 'suburb'

4. 'Apile' is a typical form like an inverted letter ' $v$ '.

5. 'Préface' to Joyal, (2009). The term intérité is suggested by Hess.

6. One can find a first review in Vega's works, but also in all textual documents (press, anonym chronicles and dance manuals) edited in early years of XX century (see also Salas 1989). All 
these sources provided the basis for an imaginary foundation of tango, on one side, as a really Argentinian and passionate practice and, on the other side, as a transcultural (see Pelinski 2009) practice where different musical and dance features could converge in a new original form. This form, as we tried to explain here, is at the same time, bodily (the abrazo with its bodily peculiarities), practical (embodiment of roles in dancing but in an improvisational framework) and cultural. The improvisational and transnational nature of dance - and at the begin, of tango music - had as result, on one side, the search for norms and codes (the codigos of the milonga) and, on the other side, a different and multifaceted rooting of tango in several countries that tried at the same time to refer to the same 'archetypical' tango which was constantly transposed and reinvented, in spite of several claims of authenticity coming from inside and outside of Argentina/Buenos Aires (Ruiz 1996).

\section{REFERENCES}

Agamben, Giorgio 1991. Notes sur le geste. Trafic 1: 31-6.

Agamben, Giorgio 2011. Le geste et la danse. In: Macel Christine and Emma Lavigne (eds)

Danser sa vie. Écrits sur la danse. Paris: Éditions du Centre Pompidou, 189-94.

Agamben, Giorgio 2015. L'usage des corps. Homo Sacer IV. Paris: Seuil.

Baervelt, Cor and Theo Verheggen 2012. Enactivism. In: Jan Valsiner (ed) The Oxford Handbook of Culture and Psychology, New York: Oxford University Press, 165- 90.

Berthoz, Alain 1997. Le sens du mouvement. Paris: Odile Jacob.

Berthoz, Alain and Gérard Jorland (eds) 2004. L'empathie. Paris: Odile Jacob.

Bouissace, Paul 1973. La mesure des gestes. Prolégomènes à la sémiotique gestuelle. The Hague-Paris: Mouton.

Brown, Steven and Lawrence Parson 2008. The neuroscience of Dance. Scientific American 1(299): 78-83.

Cadiot, Pierre and Yves-Marie Visetti 2001. Motifs, profils, themes. Pour une théorie des forms sémantiques. Paris: Presses Universitaires de France.

Calvo-Merino Beatriz, Jola, Corinne, Glaser, Daniel and Patrick Haggard 2008. Towards a sensorimotor aesthetics of performing art. Consciousness and Cognition 17: 911-22.

Decety, Jean 2004. L'empathie est-elle une simulation mentale de la subjectivité d'autrui? In: Alain Berthoz and Gérard Jorland (eds) (2004). L' empathie, Paris: Odile Jacob, 53-88.

De Luca, Valeria 2016. Les univers sémiotiques de la danse. Formes et parcours du sens dans le tango argentin. Ph. D. Thesis, Department of Semiotics, Université de Limoges. Available from: https://tel.archives-ouvertes.fr/tel-01466263/document

Dinzel, Gloria and Rodolfo Dinzel 1999. El tango: una danza. Esa ansiosa búsqueda de la libertad. Buenos Aires: Corregidor. 
74 Gesture as a device for converging of sensory and semiotic modes and levels

Fabbri, Véronique 2007. Danse et philosophie. Une pensée en construction. Paris: L'Harmattan. Ferrari, Lidia 2011. Tango. Arte y misterio de un baile. Buenos Aires: Corregidor.

Fontanille, Jacques 2004. Soma et Séma. Figures du corps. Paris: Maisonneuve \& Larose.

Fontanille, Jacques 2008. Pratiques sémiotiques. Paris: Presses Universitaires de France.

Fontanille, Jacques 2010. Une sémiotique du son? Remarques sur la constitution d'un plan d'immanence. Actes Sémiotiques 113. Available from: http://epublications.unilim.fr/revues/ as/2823

Fontanille, Jacques 2011. Corps et sens. Paris: Presses Universitaires de France.

Fontanille, Jacques 2014. L'énonciation pratique: exploration, schématisation et transposition. Communication au Colloque Common'14, Liège. Available from: http://www.lucid.ulg.ac.be/ conferences/common14/downloads/Expose\%20Jacques\%20Fontanille.pdf

Georgieff, Nicolas 2008. L'empathie aujourd'hui: au croisement des neurosciences, de la psychopathologie et de la psychanalyse. La psychiatrie de l'enfant 51(2): 357-93.

Greimas, Algirdas J. 1968. Conditions d'une sémiotique du monde naturel. Langages 10: 3-35. Joyal, France (ed) 2009. Tango, corps à corps culturel. Danser en tandem pour mieux vivre. Québec: Presses Universitaires du Québec.

Joyal, France (es) 2010. Tango sans frontières. Québec: Presses Universitaires du Québec.

Kimmel, Michael 2012. Intersubjectivity at Close Quarters: How Dancers of Tango Argentino Use Imagery for Interaction and Improvisation. Journal of Cognitive Semiotics 4(1): 76-124. Koehne, Svenija, Schidt Mirjam J. and Isabel Dziobek 2016. The role of interpersonal movement synchronisation in empathic fonctions: Insights from Tango Argentino and Capoeira. International Journal of Psychology 51: 318-22.

Kristeva, Julia 1968. Le geste, pratique ou communication? Langages 10: 48-64.

Lala, Giorgio (ed) 2005. Tangologia 2. Tango argentino: la grande guida. Musica, storia, danza, passi, figure, improvvisazione, stile milonguero, milonga, vals. Lecce: Sigillo.

Langer, Susanne 1953. Feeling and Form. A theory of art. New York: Charles Scribner's Sons.

Landowski, Eric 2004. Passion sans nom. Paris: Presses Universitaires de France.

Landowski, Eric 2005. Les interactions risquées. Nouveaux Actes Sémiotiques 101-102-103, Limoges: Pulim.

Manning, Erin 2007. Politics of touch. Sens, movement, sovereignity. Minneapolis: Minnesota Press.

Morel, Hernán 2013. “Así se baila el tango": milongueros, políticas y campeonatos de bail en la ciudad de Buenos Aires. ILHA Revista de Antropologia 15/2: 251-275.

Nanni, Dionísia, and Hugo Rodolfo Lovisolo 2011. La visión científico-pedagógica del tango y de la samba en la obra de Rodolfo Dinzel y en las teorías de Laban. Revista Motricidad Humana 12(8): 40-50.

Olivier, Gerard 2012. La cognition gestuelle. Ou de l'écho à l'égo. Grenoble: Presses Universitaires de Grenoble. 
Pelinski, Ramón 2009. El tango nómade. Ensayos sobre la diáspora del tango. Buenos Aires: Corregidor.

Petit, Jean-Luc (2004). Empathie et intersubjectivité. In: Alain Berthoz and Gérard Jorland (eds) L'empathie. Paris: Odile Jacob, 123-147.

Plisson, Michel 2001. Tango. Du noir au blanc. Paris: Cité de la Musique/Arles: Actes Sud.

Proca-Ciortea, Vera and Anca Giurchescu 1968. Quelques aspects théoriques de l'analyse de la danse populaire. Langages 10: 87-93.

Ruiz, Irma 1996. Componentes simbólicos de la transregionalización del tango. TRANS 2. Available from: http://www.sibetrans.com/trans/articulo/285/componentes-\%20simbolicos-de-la\%20transregionalizacion-del-tango

Salas, Horacio 1989. Le Tango. Arles: Actes Sud.

Sonesson, Göran 2009. Au-delà du langage de la danse - les significations du corps. Quelques considérations au sujet d'une sémiotique de la danse. Degrés. Revue de Synthèse à Orientation Sémiologique 139-140: C1-C25.

Tateo, Luca 2014. The Dialogical Dance: Self, Identity, Construction, Positioning and Embodiment in Tango Dancers. Integrative Psychological and Behavioral Science 48(3): 299-321.

Thom, René 1990. Apologie du logos. Paris: Hachette.

Van Alphen, Foor 2014. Tango and Enactivism: First Steps in Exploring the Dynamics and Experience of Interaction. Integrative Psychological and Behavioral Science 48(3): 322-31.

Vega, Carlos 1967. Las especies homónimas y afines de 'Los orígenes del tango argentino'. Revista Musical Chilena 21(101): 49-65.

Violi, Patrizia 2008. Beyond the Body: Towards a full embodied semiosis. In: Frank Roslyn M., René Dirven, Tom Ziemke and Enrique Bernádez (eds) Body, Language and Mind, vol. 2, Berlin: Mouton de Gruyter, 241-64.

Violi, Patrizia 2009. How our Bodies Us: Embodiment, Semiosis and Intersubjectivity. Cognitive Semiotics IV(1): 57-75.

Valeria De Luca holds a Phd from the Centre de Recherches Sémiotiques at Université de Limoges, France

Email: v.deluca.83@gmail.com 